\title{
Australian Acacia spp. extracts as natural food preservatives: Growth inhibition of food spoilage and food poisoning bacteria
}

\author{
Ian Edwin Cock $\mathrm{a}^{\mathrm{a}, \mathrm{b}^{*}}$ \\ aEnvironmental Futures Research Institute, Griffith University, 170 Kessels Rd, Nathan, Brisbane, Queensland 4111, AUSTRALIA \\ bSchool of Natural Sciences, Griffith University, 170 Kessels Rd, Nathan, Brisbane, Queensland 4111, Australia
}

\begin{abstract}
Introduction: A. auriculiformis, A. disparrima and A. leptoloba are native Australian Acacia spp. which were used as both foods and medicines by the first Australians. Infusions and decoctions produced from leaves and bark have reputed antiseptic properties and were used traditionally to treat a variety of bacterial diseases. Despite this, Australian Acacia spp. solvent extractions have not been rigorously examined for antibacterial properties against food spoilage and food poisoning bacteria. Methods: The antimicrobial activity of $A$. auriculiformis, $A$. disparrima and $A$. leptoloba leaf extracts extractions was investigated by disc diffusion and growth time course assays against a panel of food spoilage and food poisoning bacteria. The growth inhibitory activity was quantified by MIC determination. Toxicity was determined using the Artemia franciscana nauplii bioassay. Results: A. auriculiformis, $A$. disparrima and $A$. leptoloba leaf extracts inhibited the growth of a wide range of bacterial species which cause food spoilage and food poisoning. A. auriculiformis extracts were generally more potent growth inhibitors than extracts prepared from the other species, although A. disparrima extracts were also potent inhibitors of bacterial growth. With few exceptions, the methanolic extracts were more potent growth inhibitors than the other solvent extractions. The methanolic $A$. auriculiformis leaf extract was a particularly potent inhibitor of $K$. pneumoniae and $P$. mirabilis, B. cereus and S. aureus growth, with MIC values of 97, 132, 178 and 109 $\mu \mathrm{g} / \mathrm{mL}$ respectively. This extract was also a good inhibitor of $A$. faecalis,
\end{abstract}

A. hydrophilia and S. newport growth (MIC's $<1000 \mu \mathrm{g} / \mathrm{mL}$ range) The $A$. disparrima extracts had a similar, albeit slightly less potent activity profiles. In contrast, the $A$. leptoloba leaf extracts were substantially less potent. All extracts were determined to be nontoxic in the Artemia franciscana nauplii bioassay, indicating their safety for use as natural food preservatives. Conclusions: The lack of toxicity of the $A$. auriculiformis, $A$. disparrima and A. leptoloba leaf extracts and their growth inhibitory bioactivity against a panel of food spoilage and food poisoning bacteria indicate their potential in the development of natural food preservatives.

Key words: Acacia auriculiformis, Acacia disparrima, Acacia leptoloba, Fabaceae, Natural food preservatives, Australian plants, Antibacterial activity, Medicinal plants.

\section{Correspondence:}

Ian Edwin Cock, Environmental Futures Research Institute,

Griffith University, 170 Kessels Rd, Nathan, Brisbane, Queensland 4111, AUSTRALIA

Phone no: +61 737357637 ; fax: +61 737355282

E-mail: I.Cock@griffith.edu.au (I. E. Cock)

DOI : 10.5530/pc.2017.1.2

\section{INTRODUCTION}

Food loss through spoilage is a major global problem. Spoilage can render food unpalatable and/or increase the risks of diseases and food poisoning and can be caused by a variety of physiochemical causes and biological agents. Of perhaps most concern to the food production industry is microbial induced food spoilage and food poisoning. Incidences of food-borne illnesses were estimated at 76 million cases annually in the USA alone in a 1999 study, with at least 5000 deaths annually directly attributed to food poisoning. ${ }^{1}$ This is an area of concern to the food industry and there is considerable effort to develop improved preservation strategies. Methods aimed at inhibiting microbial growth in food must control initial populations as well as regrowth of post-processing microbial survivors and contaminant induced populations. This may be achieved by several methodologies including alteration of temperature (heating, chilling), $\mathrm{pH}$, water activity (fermentation or dehydration) or oxygen availability (canning, shrink wrap, reduced oxygen packaging, high pressures), irradiation or by chemical preservation. ${ }^{2}$

A major method of controlling food-borne microbes and thereby reducing spoilage and food toxin production is through the use of chemical preservatives. Commonly used chemical food preservatives include butylhydroxyanisol (BHA), butylated hydroxytoluene (BHT), calcium propionate, nitrates, nitrites, sulphur dioxide $\left(\mathrm{SO}_{2}\right)$ and sulfites $\left(\mathrm{SO}_{3}\right){ }^{2}$ The effectiveness of these chemical preservatives is dependent on the type of microbial flora and the physical and chemical characteristics of the food. ${ }^{2-4}$ However, the safety of many of the chemical food preservatives used in food has yet to be determined and in some cases these preservatives have been linked with serious health problems. Indeed, chemical preservatives may cause respiratory problems, ${ }^{4}$ aggravate attention deficit hyperactivity disorder $(\mathrm{ADHD})^{5}$ and cause anaphylactic shock in susceptible individuals. ${ }^{4}$

Consumers are increasingly avoiding foods containing synthetic preservatives due to greater consumer awareness and the negative perceptions of artificial preservatives. Instead, natural antimicrobial alternatives are increasingly being sought to increase the shelf life and safety of processed foods. ${ }^{6}$ Plant extracts and oils are candidates for antimicrobial agents that would be more acceptable to consumers due to their natural origin and consumer perception of safety. In addition, many plants have well established antimicrobial activity and several plant species have already been identified for their potential as natural preservatives. ${ }^{7-12}$

The genus Acacia (family Fabaceae, subfamily Mimosaceae) consists of over 1200 species of which more than 700 are indigenous to Australia ${ }^{13}$ Other species are spread throughout tropical to warm temperate regions of Africa, India and the Americas. Acacias have also been introduced globally for ornamental and economic purposes. Most Acacia species produce quality wood and some are also valuable sources of proteins, tannins, gum, perfumes, paint, ink and flavouring agents. ${ }^{14,15}$ Furthermore, Acacia seed formed an important part of the diet for Australian Aborigines as an easily obtainable, high energy food. ${ }^{16,17}$ Acacia seed can easily be ground to a flour which is then mixed with water and eaten 
either raw or cooked to produce an unleavened bread. Powdered Acacia seed flour inhibits the growth of several species of food spoilage bacteria and thus has potential as natural food preservatives. ${ }^{18}$ Other parts of some Acacia species are also eaten. Several species exude a sugary gum from wounds to the stem and branches ${ }^{14,17}$ whilst others are hosts for edible grubs often referred to as witchetty grubs by non-Aboriginal Australians. ${ }^{19}$

Australian Acacia species were also used as traditional bush medicines by the first Australians. Several species were used to prepare antimicrobial washes and lotions. ${ }^{20,21}$ Unfortunately most of our understanding of the antimicrobial potential of Australian Acacia species is anecdotal with few species being rigorously studied. These anecdotal accounts demonstrate that the first Australians knew of the antibacterial properties of the Australian Acacia spp. and used them for an array of therapeutic purposes to treat many diseases (Table 1).

Recent studies ${ }^{20,21}$ have demonstrated the antibacterial activity of methanolic extracts of several species of Australian Acacia against a limited panel of bacteria. However, the therapeutic properties of many other Australian Acacia spp. are yet to be investigated. The current study was undertaken to assess the growth inhibitory properties of 3 species of Australian Acacia spp. (Acacia auriculiformis A.Cunn. Ex Benth., Acacia disparrima M.W.McDonald \& Maslin and Acacia leptoloba) with documented antiseptic uses against of a panel of food spoilage and food poisoning bacteria. Furthermore, the toxicity of the extracts was evaluated to further assess their suitability as natural food preservatives.

\section{MATERIALS AND METHODS}

\section{Plant collection and extraction}

Acacia auriculiformis A.Cunn. Ex Benth., Acacia disparrima M.W.McDonald \& Maslin and Acacia leptoloba Pedley leaves were obtained from, and identified by, Philip Cameron, senior botanic officer, Mt Cootha Botanical Gardens, Brisbane, Australia. The leaf samples were dried in a Sunbeam food dehydrator and stored at $-30^{\circ} \mathrm{C}$. Prior to use, the dried leaves were freshly ground to a coarse powder and $1 \mathrm{~g}$ quantities were weighed into separate tubes. A volume of $50 \mathrm{~mL}$ methanol, sterile deionised water, ethyl acetate, chloroform or hexane was added to individual tubes and extracted for $24 \mathrm{hr}$ at $4^{\circ} \mathrm{C}$ with gentle shaking. All solvents were obtained from Ajax, Australia and were AR grade. The extracts was filtered through filter paper (Whatman No. 54) under vacuum, followed by drying by rotary evaporation in an Eppendorf concentrator 5301. The resultant pellets were dissolved in $10 \mathrm{~mL}$ sterile deionised water (containing 1\% DMSO). The extracts were passed through $0.22 \mu \mathrm{m}$ filter (Sarstedt) and stored at $4^{\circ} \mathrm{C}$ until use.

\section{Qualitative phytochemical studies}

Phytochemical analysis of the A. auriculiformis, A. disparrima and A. leptoloba leaf extracts for the presence of saponins, phenolic compounds, flavonoids, phytosteroids, triterpenoids, cardiac glycosides, anthraquinones, tannins and alkaloids was conducted by previously described assays. $^{22-24}$

\section{Antibacterial screening Test microorganisms}

All media was supplied by Oxoid Ltd., Australia. Clinical isolate microbial strains of Aeromonas hydrophilia, Alcaligenes feacalis, Bacillus cereus, Citrobacter freundii, Escherichia coli, Klebsiella pneumoniae, Proteus mirabilis, Pseudomonas fluorescens, Salmonella newport, Serratia marcescens, Shigella sonneii, Staphylococcus aureus, Staphylococcus epidermidis and Streptococcus pyonenes were obtained from Ms Michelle Mendell and Ms Jane Gifkins, Griffith University. All stock cultures were subcultured and maintained in nutrient broth at $4^{\circ} \mathrm{C}$.

\section{Evaluation of antimicrobial activity}

Antimicrobial activity of all Acacia leaf extracts was determined using a modified disc diffusion assay. ${ }^{25-27}$ Briefly, $100 \mu \mathrm{L}$ of each bacterial culture was grown in $10 \mathrm{~mL}$ of fresh nutrient broth until they reached a count of $\sim 10^{8}$ cells $/ \mathrm{mL}$. A volume of $100 \mu \mathrm{L}$ of the bacterial suspension was spread onto nutrient agar plates and extracts were tested for antibacterial activity using $5 \mathrm{~mm}$ sterilised filter paper discs. Discs were infused with $10 \mu \mathrm{L}$ of the plant extracts, allowed to dry and placed onto the inoculated plates. The plates were allowed to stand at $4^{\circ} \mathrm{C}$ for $2 \mathrm{~h}$ before incubation at $30^{\circ} \mathrm{C}$ for $24 \mathrm{~h}$. The diameters of the inhibition zones were measured to the closest whole millimetre. Each assay was performed in at least triplicate. Mean values $( \pm$ SEM) are reported in this study. Standard discs of ampicillin $(10 \mu \mathrm{g})$ were obtained from Oxoid, Australia and were used as positive controls to compare antibacterial activity. Filter discs infused with $10 \mu \mathrm{L}$ of distilled water were used as a negative control.

\section{Minimum inhibitory concentration (MIC) determination}

The minimum inhibitory concentration (MIC) of each extract against susceptible bacteria was determined as previously described. ${ }^{28,29}$ Briefly, the A. auriculiformis, A. disparrima and A. leptoloba leaf extracts were diluted in deionised water and tested across a range of concentrations. Discs were infused with $10 \mu \mathrm{L}$ of the test dilutions, allowed to dry and placed onto inoculated plates. The assay was completed as outlined above and graphs of the zone of inhibition versus concentration were plotted for each extract. Linear regression was used to determine the MIC values of each extract.

\section{Bacterial growth time course assay}

Bacterial growth time course studies were performed as previously described. ${ }^{30}$ Briefly, $3 \mathrm{~mL}$ of the K. pneumoniae and P. mirabilis cultures in nutrient broth were added to $27 \mathrm{~mL}$ nutrient broth containing $3 \mathrm{~mL}$ of $10 \mathrm{mg} / \mathrm{mL}$ methanolic plant extract to give a final concentration of $1000 \mu \mathrm{g} / \mathrm{mL}$ in the assay. The tubes were incubated at $30^{\circ} \mathrm{C}$ with gentle shaking. The optical density was measured hourly at $550 \mathrm{~nm}$ for a $6 \mathrm{~h}$ incubation period. Control tubes were incubated under the same conditions but without the extract. All assays were performed in triplicate.

\section{Toxicity screening}

\section{Reference toxin for toxicity screening}

Potassium dichromate $\left(\mathrm{K}_{2} \mathrm{Cr}_{2} \mathrm{O}_{7}\right)$ (AR grade, Chem-Supply, Australia) was prepared as a $4 \mathrm{mg} / \mathrm{mL}$ solution in distilled water and was serially diluted in artificial seawater for use in the Artemia franciscana nauplii bioassay.

\section{Artemia franciscana nauplii toxicity screening}

Toxicity was tested using an adapted Artemia franciscana nauplii lethality assay. ${ }^{31-33}$ Briefly, $400 \mu \mathrm{L}$ of seawater containing approximately 52 (mean 52.4, $\mathrm{n}=75, \mathrm{SD} 15.2$ ) A. franciscana nauplii were added to wells of a 48 well plate and immediately used for bioassay. A volume of $400 \mu \mathrm{L}$ of diluted plant extracts or the reference toxin were transferred to the wells and incubated at $25 \pm 1^{\circ} \mathrm{C}$ under artificial light (1000 Lux). A $400 \mu \mathrm{L}$ seawater negative control was run in triplicate for each plate. All treatments were performed in at least triplicate. The wells were checked at regular intervals and the number of dead counted. The nauplii were considered dead if no movement of the appendages was detected within 10 seconds. After $24 \mathrm{~h}$, all nauplii were sacrificed and counted to determine the total $\%$ mortality per well. The $\mathrm{LC}_{50}$ with $95 \%$ confidence limits for each treatment was determined using probit analysis.

\section{Statistical analysis}

Data are expressed as the mean \pm SEM of at least three independent experiments. One way ANOVA was used to calculate statistical significance 
Table 1: The ethnobotanical usage, synonyms and common names of the Acacia species tested in this study.

\begin{tabular}{|c|c|c|c|c|c|c|}
\hline Plant Species & Synonym & Common Name & $\begin{array}{l}\text { Part Used } \\
\text { Medicinally }\end{array}$ & $\begin{array}{l}\text { Part Used in } \\
\text { This Study }\end{array}$ & Medicinal Use & References \\
\hline $\begin{array}{l}\text { Acacia } \\
\text { auriculiformis } \\
\text { A.Cunn. Ex } \\
\text { Benth. }\end{array}$ & $\begin{array}{c}\text { Acacia } \\
\text { moniliformis } \\
\text { Griseb., } \\
\text { Racosperma } \\
\text { auriculiforme } \\
\text { (Benth.) Pedley }\end{array}$ & $\begin{array}{l}\text { earleaf acacia, earpod } \\
\text { wattle, northern black } \\
\text { wattle. Papuan wattle, } \\
\text { tan wattle }\end{array}$ & $\begin{array}{l}\text { The leaves and } \\
\text { and seed pods are } \\
\text { used as extracts, } \\
\text { decoctions or } \\
\text { infusions. }\end{array}$ & leaves & $\begin{array}{l}\text { A decoction of the leaves was applied to } \\
\text { cuts and wounds. A leaf decoction and a } \\
\text { lather prepared from crushed ripe seed } \\
\text { pods was used to treat itchy skin and } \\
\text { several skin disorders and rashes. An } \\
\text { infusion prepared from leaves and seed } \\
\text { pods was used as an analgesic }\end{array}$ & 20,21 \\
\hline $\begin{array}{l}\text { Acacia } \\
\text { disparrima } \\
\text { M.W.McDonald } \\
\text { \& Maslin }\end{array}$ & $\begin{array}{c}\text { Acacia } \\
\text { aulacocarpa } \\
\text { Morrison } \\
\text { \& Davies, } \\
\text { Racosperma } \\
\text { disparrimum } \\
\text { (M.W.McDonald } \\
\text { \& Maslin) Pedley }\end{array}$ & $\begin{array}{l}\text { Hickory wattle, } \\
\text { Southern Salwood }\end{array}$ & $\begin{array}{l}\text { The leaves, seed } \\
\text { pods and bark are } \\
\text { used as extracts, } \\
\text { decoctions or } \\
\text { infusions. }\end{array}$ & leaves & $\begin{array}{l}\text { A decoction of the leaves was applied to } \\
\text { cuts and wounds. A leaf decoction and a } \\
\text { lather prepared from crushed ripe seed } \\
\text { pods was used to treat itchy skin and } \\
\text { several skin disorders and rashes. An } \\
\text { infusion prepared from leaves and seed } \\
\text { pods was used as an analgesic }\end{array}$ & 20,21 \\
\hline $\begin{array}{c}\text { Acacia leptoloba } \\
\text { Pedley }\end{array}$ & $\begin{array}{c}\text { Racosperma } \\
\text { leptolobum Pedley }\end{array}$ & Irvinebank wattle & leaves & leaves & $\begin{array}{l}\text { Seed pods are mashed and a decoction } \\
\text { is prepared. This is applied to infected } \\
\text { eyes. The decoction is also used to treat } \\
\text { skin disorders and as a wound antiseptic. }\end{array}$ & 20,21 \\
\hline
\end{tabular}

between control and treated groups with a $P$ value $<0.01$ considered to be statistically significant.

\section{RESULTS}

\section{Liquid extraction yields and qualitative phytochemical screening}

Extraction of $1 \mathrm{~g}$ of dried and powdered A. auriculiformis, A. disparrima and $A$. leptoloba leaves with solvents of varying polarity yielded dried extracts ranging from $25 \mathrm{mg}$ (A. auriculiformis hexane extract) to $150 \mathrm{mg}$ (aqueous A. leptoloba extract) (Table 2). The methanolic and aqueous extracts of all Acacia spp. produced high yields (generally $>100 \mathrm{mg}$ ). Cloroform also extracted relatively high masses of extracted material (80-100 mg). In contrast, ethyl acetate and hexane extracted only low masses for all Acacia spp. (25-35 mg). The dried extracts were resuspended in $10 \mathrm{~mL}$ of deionised water (containing 1\% DMSO), resulting in the extract concentrations shown in Table 2.

Qualitative phytochemical studies showed that the higher polarity methanol and water solvents generally extracted the greatest diversity and highest levels of phytochemicals. These extracts of all Acacia spp. contained high levels of polyphenolics (particularly water soluble phenolics), saponins, flavonoids and tannins. They also contained low levels of phytosterols and alkaloids. All ethyl acetate extracts contained similar phytochemical classes, albeit generally at lower levels. Interestingly, despite extracting relatively large amounts of material, the chloroform and hexane extracts were generally devoid of all classes of phytochemicals screened. Due to their nonpolar nature, these extracts would be expected to contain high levels of lipids, hydrocarbons etc. As our qualitative phytochemical studies did not screen for these compounds, they were not detected and other techniques are required to further examine the nature of these nonpolar components.

\section{Antimicrobial activity}

To determine the growth inhibitory activity of the A. auriculiformis, A. disparrima and A. leptoloba leaf extracts against the panel of pathogenic bacteria, aliquots $(10 \mu \mathrm{L})$ of each extract were screened in the disc diffusion assay. The methanolic, aqueous and ethyl acetate extracts of
A. auriculiformis inhibited a broad spectrum of gram negative (Figure 1a) and gram positive bacterial species (Figure 1b). Indeed, the methanolic, aqueous and ethyl acetate extracts inhibited 9 (90\%), 8 (80\%) and 8 (80\%) of the gram negative bacteria screened. Furthermore, the methanolic, aqueous and ethyl acetate extracts all inhibited $100 \%$ of the gram positive bacteria tested. The methanolic extract was the most potent growth inhibitor (as assessed by the sizes of the zones of inhibition). It was a particularly potent inhibitor of $K$. pneumoniae, $P$. mirabilis and $S$. aureus growth, with zones of inhibition of $10.6 \pm 0.6 \mathrm{~mm}, 9.6 \pm 0.3 \mathrm{~mm}$ and $12.5 \pm 1.0 \mathrm{~mm}$ respectively. This inhibition was particularly noteworthy compared to the inhibition by the ampicillin control $(10 \mu \mathrm{g}$ : inhibition zones of approximately $8 \mathrm{~mm}$ for each of these bacteria). The chloroform extracts also inhibited the growth of a range of bacteria (4 gram negative bacteria (40\%) and 2 gram positive bacteria (50\%), albeit generally with substantially smaller inhibition zones than were recorded for methanolic, aqueous and ethyl acetate extracts. The hexane extract was devoid of growth inhibitory activity.

A similar trend was noted for the A. disparrima leaf extracts, although less bacterial species were inhibited (Figure $2 \mathrm{a}$ and $2 \mathrm{~b}$ ). The methanolic and aqueous extracts were again the most potent growth inhibitors. However, the $A$. disparrima leaf extracts were substantially less potent growth inhibitors than the corresponding A. auriculiformis extracts, as judged by the zones of inhibition. The A. leptoloba leaf extracts had even lower potency (Figure $3 \mathrm{a}$ and $3 \mathrm{~b}$ ). Indeed, the methanolic A. leptoloba leaf extract inhibited only 6 of the 14 bacterial species screened (43\%), and generally with only small zones of inhibition $(<7 \mathrm{~mm})$.

The antimicrobial efficacy was further quantified by determining the MIC values for each extract against the microbial species which were determined to be susceptible. The methanolic, aqueous and ethyl acetate $A$. auriculiformis and $A$. disparrima leaf extracts were potent growth inhibitors of several bacterial species (as judged by MIC; Table 3). $K$. pneumoniae and P. mirabilis, B. cereus and S. aureus were the most susceptible bacteria to the $A$. auriculiformis and A. disparrima leaf extracts, with MIC values generally $<500 \mu \mathrm{g} / \mathrm{mL}(<5 \mu \mathrm{g}$ infused into the disc) recorded for the aqueous and methanolic extracts against these bacteria. The potency of the methanolic A. auriculiformis extract was 
Table 2: The mass of dried extracted material, the concentration after resuspension in deionised water and qualitative phytochemical screenings of the methanolic A. auriculiformis, A. disparrima and A. leptoloba extracts.

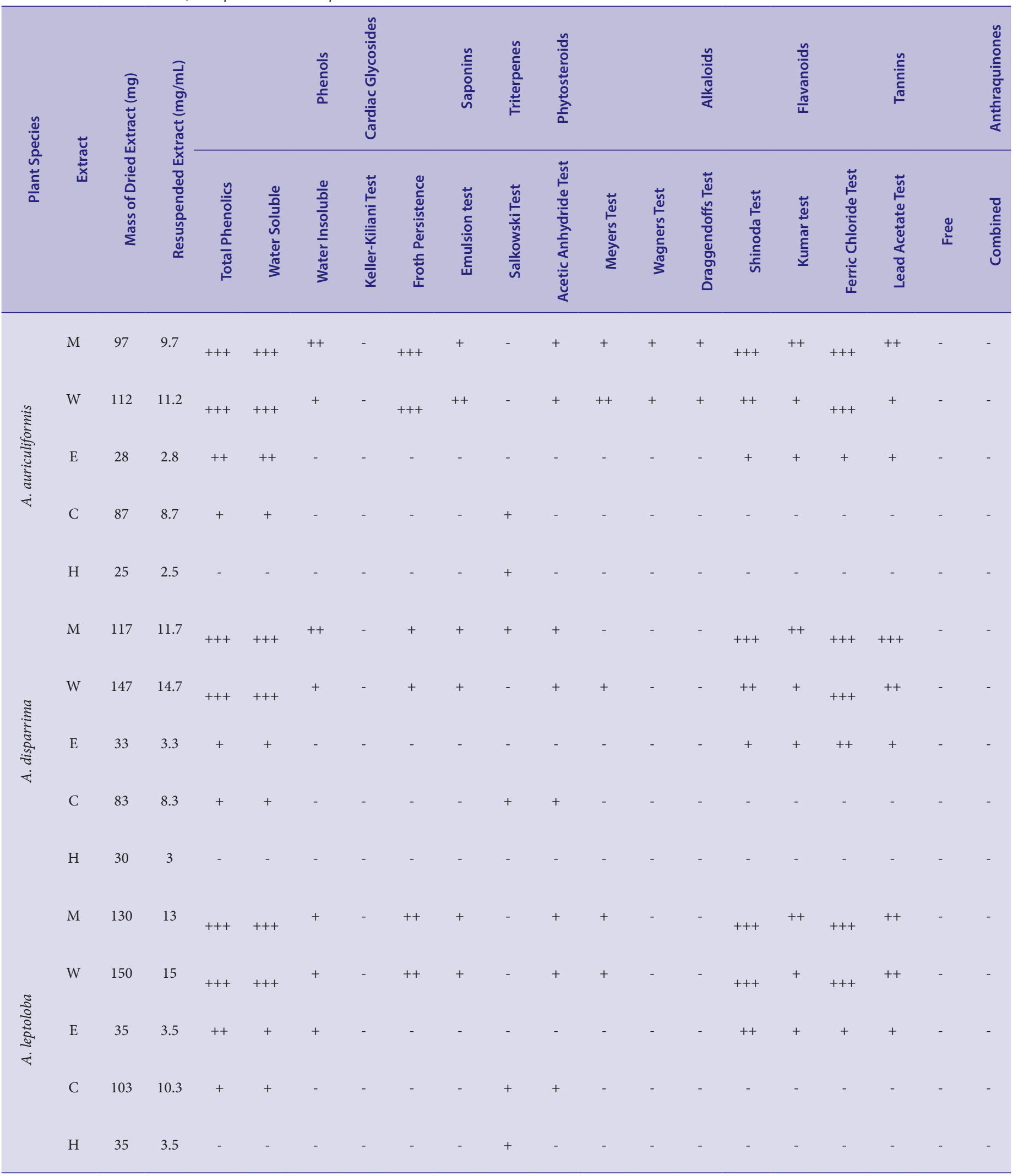

+++ indicates a large response; ++ indicates a moderate response; + indicates a minor response; - indicates no response in the assay. 
Table 3: Minimum bacterial growth inhibitory concentration $(\mu \mathrm{g} / \mathrm{mL})$ of the A. auriculformis, A. disparrima and A. leptoloba extracts.

\begin{tabular}{|c|c|c|c|c|c|c|c|c|c|c|c|c|c|c|c|}
\hline \multirow{2}{*}{ Bacteria } & \multicolumn{5}{|c|}{ A. auriculiformis } & \multicolumn{5}{|c|}{ A. disparrima } & \multicolumn{5}{|c|}{ A. leptoloba } \\
\hline & $M$ & w & $\mathrm{E}$ & C & H & $M$ & w & $E$ & C & $\mathrm{H}$ & $M$ & w & $E$ & C & $\mathrm{H}$ \\
\hline \multicolumn{16}{|l|}{$\begin{array}{c}\text { Gram negative } \\
\text { bacteria }\end{array}$} \\
\hline A. faecalis & 523 & 627 & 880 & 1282 & - & 799 & 922 & 1200 & - & - & - & - & - & - & - \\
\hline A. hydrophilia & 771 & 920 & 875 & 1693 & - & 1275 & 1186 & 1573 & - & - & 1086 & 1459 & 1472 & - & - \\
\hline C. freundi & 895 & 1018 & 1147 & - & - & - & - & - & - & - & - & - & - & - & - \\
\hline E. coli & 1266 & 1472 & 1386 & - & - & 2287 & 2639 & - & - & - & - & - & - & - & - \\
\hline K.pneumoniae & 97 & 154 & 227 & 1263 & - & 783 & 1017 & 993 & - & - & 1324 & 2488 & 1653 & - & - \\
\hline P. mirabilis & 132 & 188 & 203 & 697 & - & 965 & 1342 & 1728 & - & - & 1880 & 3879 & 2564 & - & - \\
\hline P. fluroscens & 803 & 1220 & 976 & - & - & - & - & - & - & - & - & - & - & - & - \\
\hline S. newport & 528 & 575 & 820 & - & - & 911 & 1235 & 1194 & - & - & 2237 & - & - & - & - \\
\hline S. marcenscens & 2405 & - & - & - & - & - & - & - & - & - & - & - & - & - & - \\
\hline S. sonnei & - & - & - & - & - & - & - & - & - & - & - & - & - & - & - \\
\hline \multicolumn{16}{|l|}{$\begin{array}{c}\text { Gram positive } \\
\text { bacteria }\end{array}$} \\
\hline B. cereus & 178 & 226 & 495 & 1147 & - & 226 & 419 & 283 & 1427 & - & 311 & 723 & - & - & - \\
\hline S. aureus & 109 & 240 & 408 & 992 & - & 476 & 589 & 770 & 2318 & - & 825 & 1425 & - & - & \\
\hline S. epidermidis & 1140 & 1825 & 2207 & - & - & 2682 & 2404 & 1665 & - & - & - & - & - & - & - \\
\hline S. pyogenes & 2085 & 2865 & 3244 & - & - & 3380 & 3674 & - & - & - & - & - & - & - & - \\
\hline
\end{tabular}

Numbers indicate the mean MIC and $\mathrm{LC}_{50}$ values of triplicate determinations. - indicates no inhibition. $\mathrm{M}=$ methanolic extract; $\mathrm{W}=$ aqueous extract; $\mathrm{E}=$ ethyl acetate extract; $\mathrm{C}=$ chloroform extract; $\mathrm{H}=$ hexane extract.

particularly noteworthy (MICs of 97, 132, 178 and $109 \mu \mathrm{g} / \mathrm{mL}$ against each of these bacteria respectively). The chloroform A. auriculiformis and $A$. disparrima leaf extracts were also moderate inhibitors of these bacteria, although the MIC values recorded were generally $>1000 \mu \mathrm{g} / \mathrm{mL}$ ( $>10 \mu \mathrm{g}$ infused into the disc).

Furthermore, the methanolic, aqueous and ethyl acetate extracts were also good A. faecalis, A. hydrophilia and S. newport growth inhibitors, with MIC values generally $<1000 \mu \mathrm{g} / \mathrm{mL}$ range. The chloroform $A$. auriculiformis and $A$. disparrima leaf extracts were generally only moderate growth inhibitors of most bacteria (MIC $>100 \mu \mathrm{g} / \mathrm{mL}$ ), although the chloroform $A$. auriculiformis extract was a potent inhibitor of $P$. mirabilis (MIC $697 \mu \mathrm{g} / \mathrm{mL}$ ). Moderate to low growth inhibition (or no inhibition) was noted for all other extract/bacterium combinations.

\section{Bacterial growth time course assay}

The antibacterial activity of the methanolic A. auriculformis and $A$. disparrima extracts was further investigated against the most susceptible bacterial species (K. pneumoniae and P. mirabilis) by bacterial growth time course assays in the presence and absence of the extract. The growth inhibitory properties of the methanolic A. leptoloba extract were not further evaluated due to it substantially lower potency (as assessed by MIC determination). Furthermore, only the effect of the methanolic extracts was evaluated as these extracts were the most potent bacterial growth inhibitors. The starting concentration of the extract used in these assays was $1000 \mu \mathrm{g} / \mathrm{mL}$. The methanolic A. auriculformis and A. disparrima extracts both significantly inhibited K. pneumoniae (Figure 4a) and $P$. mirabilis (Figure $4 \mathrm{~b}$ ) growth within $1 \mathrm{~h}$, indicating a rapid antimicrobial action. The growth of both $K$. pneumoniae and P. mirabilis were inhibited for at least the first $5 \mathrm{~h}$ of the time course. However, both bacteria were generally able to overcome the inhibition by $A$. disparrima within $6 \mathrm{~h}$, with the recorded turbidity not significantly different to that of the untreated control. This indicates that the growth inhibition of these bacteria was bacteriostatic for the methanolic A. disparrima extract at the concentrations tested. In contrast, inhibition of by the methanolic A. auriculformis extract was substantially more profound, with growth still significantly inhibited by the end of the $6 \mathrm{~h}$ time course study. This may indicate that the methanolic A. auriculformis extract may have bactericidal activity at the dose tested. Indeed, the turbidity at $6 \mathrm{~h}$ was not greatly increased from the starting turbidity.

\section{Quantification of toxicity}

The toxicity of the A. auriculformis, A. disparrima and A. leptoloba leaf extracts were initially tested in the Artemia franciscana nauplii bioassay at a concentration of $2000 \mu \mathrm{g} / \mathrm{mL}$ (Figure 5). All extracts induced low levels of mortality at $24 \mathrm{~h}$, similar to the $\%$ mortality seen for the seawater control. By 48 h, the mortality induced by the aqueous and methanolic extracts had increased although it was still not significantly higher than that in the untreated control. As all of the A. auriculformis, A. disparrima and $A$. leptoloba leaf extracts induced $<50 \%$ toxicity at $48 \mathrm{~h}$, all were deemed to be nontoxic. Extracts with an $\mathrm{LC}_{50}$ of greater than $1000 \mu \mathrm{g} / \mathrm{mL}$ towards Artemia nauplii following $24 \mathrm{~h}$ exposure have previously been defined as being nontoxic. ${ }^{33}$ In contrast, the potassium dichromate positive control induced mortality within $4 \mathrm{~h}$ (results not shown), with $100 \%$ mortality induction seen by $24 \mathrm{~h}$.

\section{DISCUSSION}

There is increasing consumer demand to find alternatives for chemical based artificial preservatives as consumers become more aware of the 

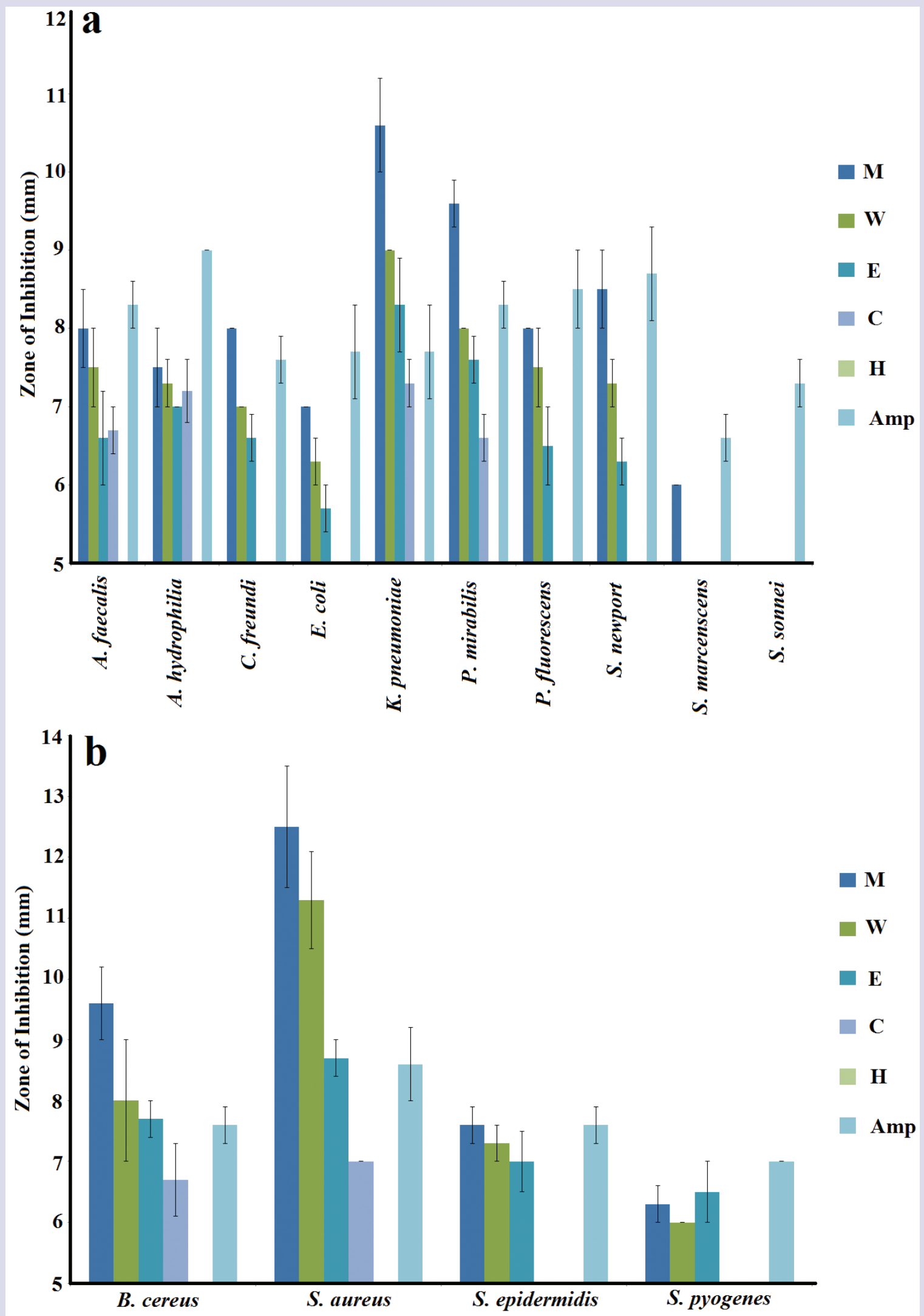

Figure 1: Growth inhibitory activity of the $A$. auriculiformis leaf extracts against (a) gram negative and (b) gram positive bacterial species and an ampicillin $(10 \mu \mathrm{g})$ control. $\mathrm{M}=$ methanolic extract; $\mathrm{W}=$ aqueous extract; $\mathrm{E}=$ ethyl acetate extract; $\mathrm{C}=$ chloroform extract; $\mathrm{H}=$ hexane extract; $\mathrm{Amp}=\mathrm{ampicillin}(10 \mu \mathrm{g})$ control. All determinations were performed in at least triplicate and the results are expressed as mean zones of inhibition $(\mathrm{mm}) \pm \mathrm{SEM}$. 


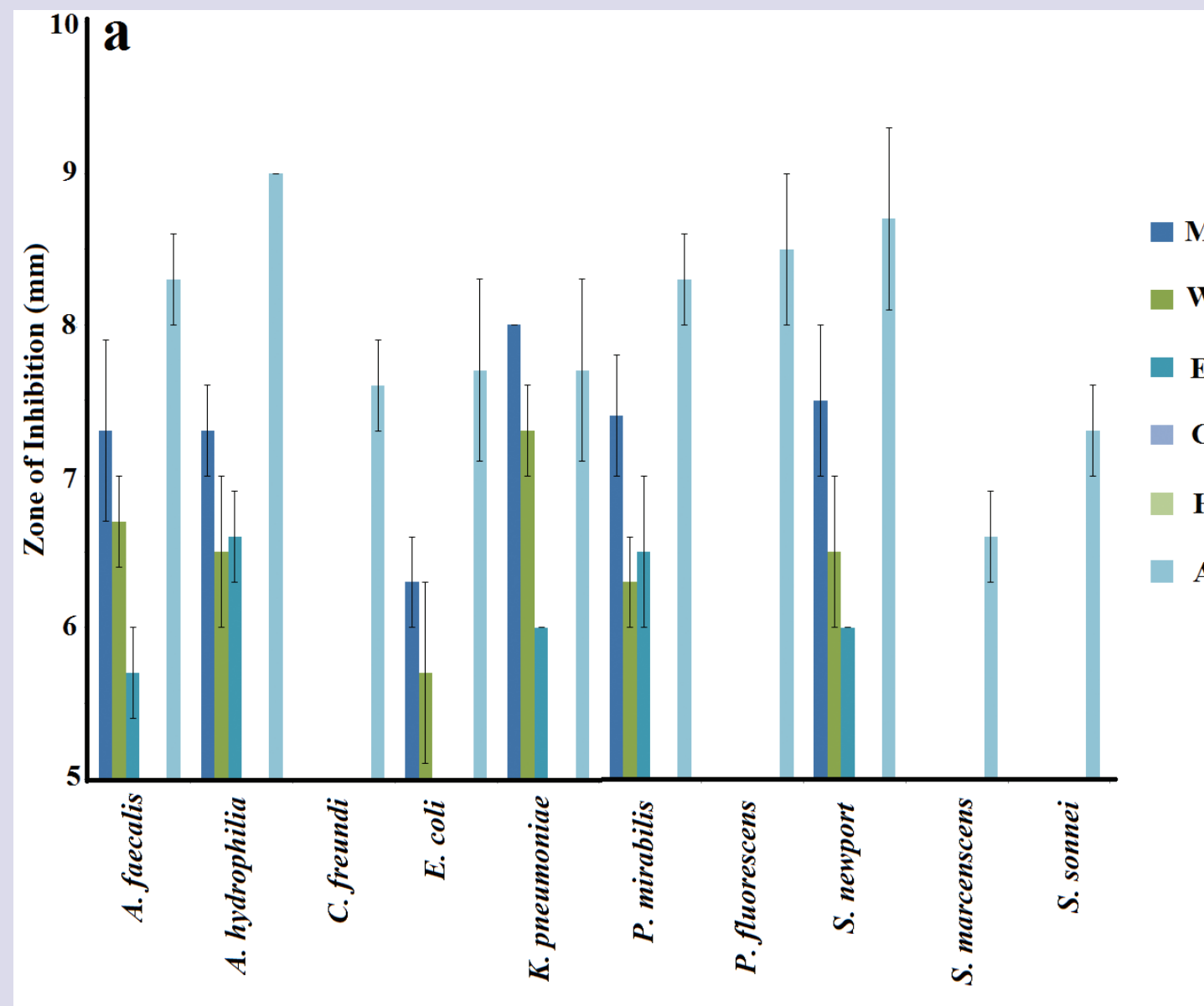

M

W

$\mathbf{E}$

C

H

Amp

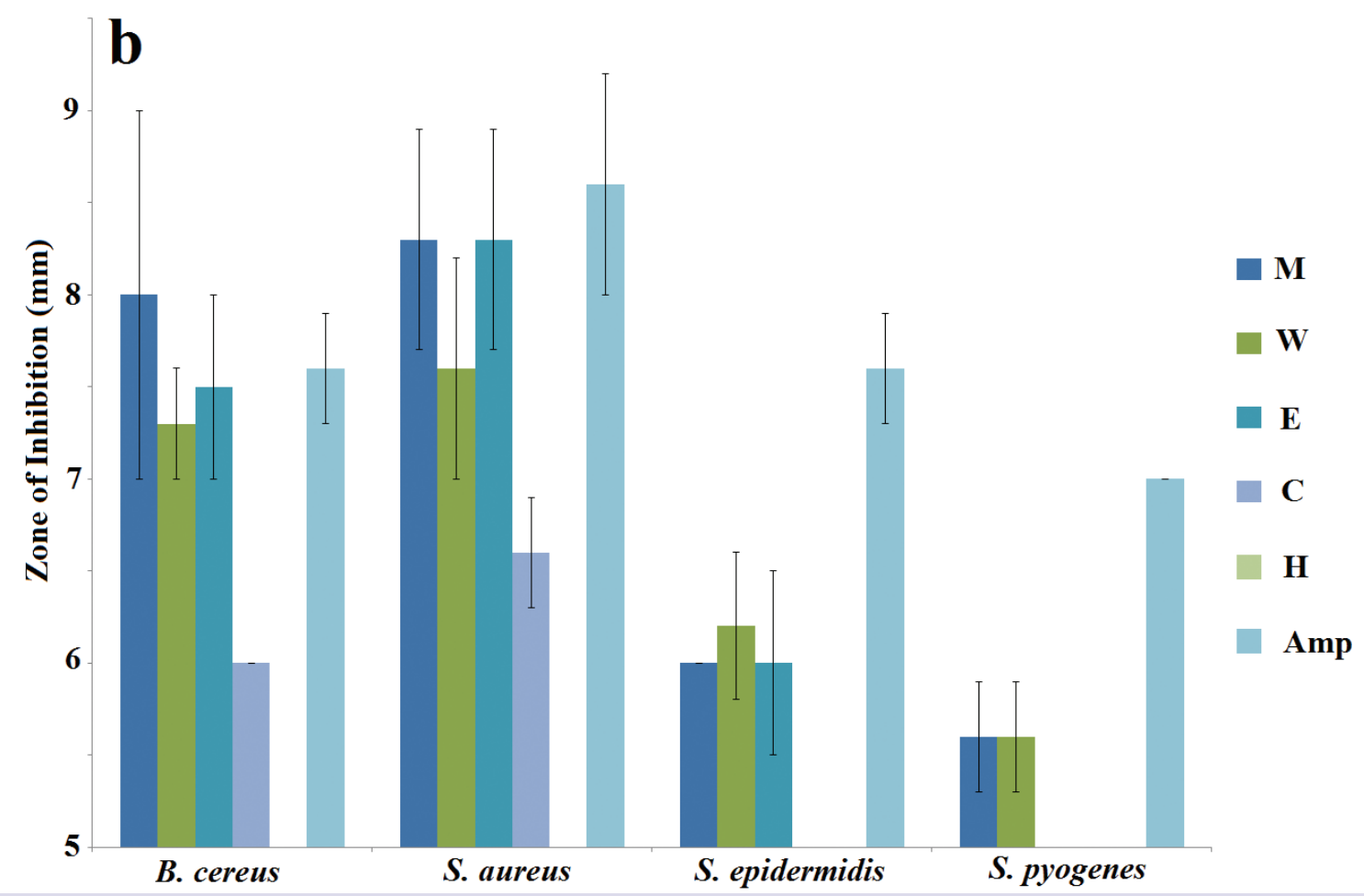

Figure 2: Growth inhibitory activity of the $A$. disparrima leaf extracts against (a) gram negative and (b) gram positive bacterial species and an ampicillin (10 $\mu \mathrm{g}$ ) control. $\mathrm{M}=$ methanolic extract; $\mathrm{W}=$ aqueous extract; $\mathrm{E}=$ ethyl acetate extract; $\mathrm{C}=$ chloroform extract; $\mathrm{H}=$ hexane extract; $\mathrm{Amp}=\mathrm{ampicillin}(10 \mu \mathrm{g})$ control. All determinations were performed in at least triplicate and the results are expressed as mean zones of inhibition $(\mathrm{mm}) \pm \mathrm{SEM}$. 


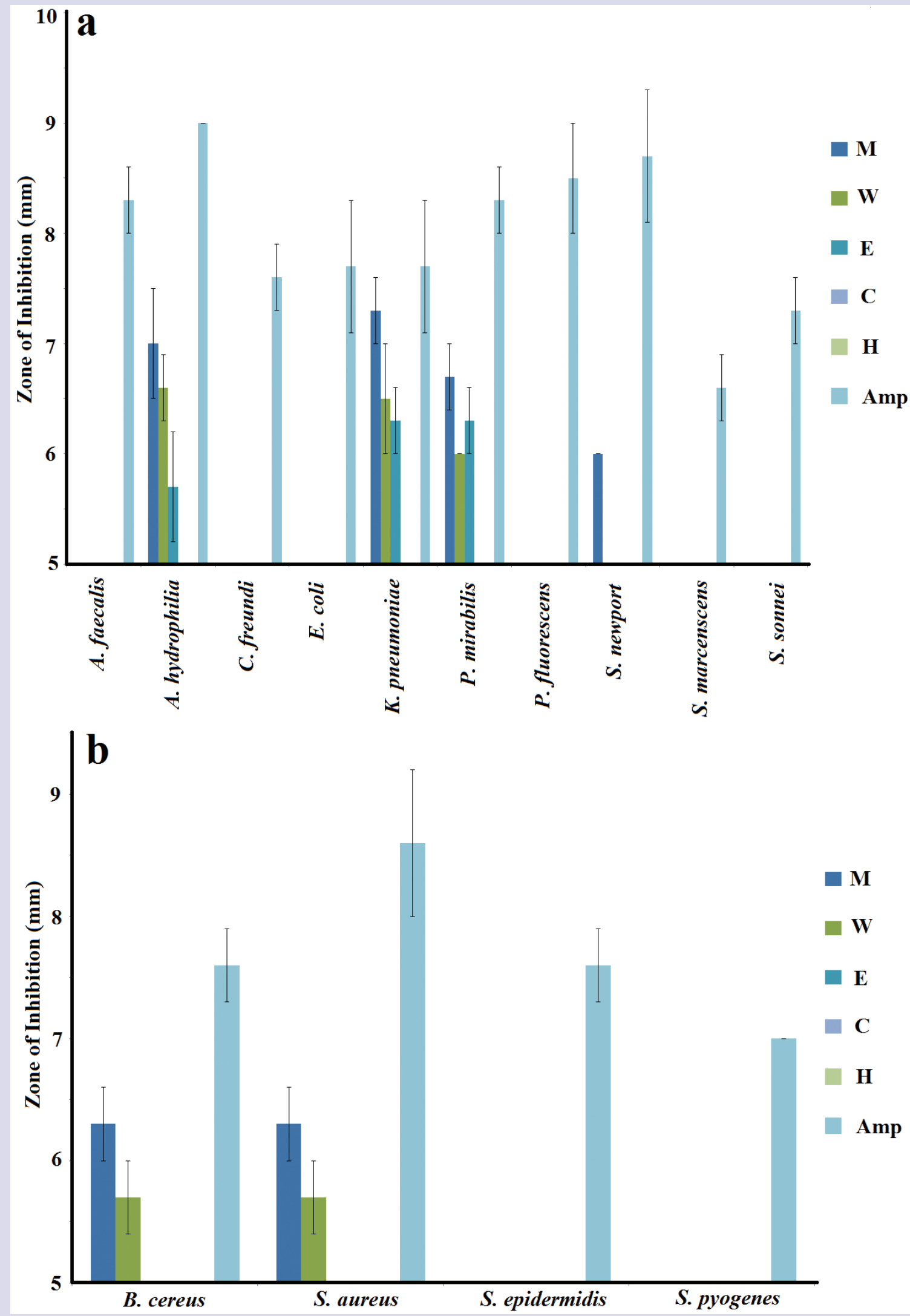

Figure 3: Growth inhibitory activity of the A. leptoloba leaf extracts against (a) gram negative and (b) gram positive bacterial species and an ampicillin (10 $\mu$ ) control. $\mathrm{M}=$ methanolic extract; $\mathrm{W}=$ aqueous extract; $\mathrm{E}=$ ethyl acetate extract; $\mathrm{C}=$ chloroform extract; $\mathrm{H}=$ hexane extract; Amp = ampicillin (10 $\mu \mathrm{g})$ control. All determinations were performed in at least triplicate and the results are expressed as mean zones of inhibition $(\mathrm{mm}) \pm \mathrm{SEM}$. 


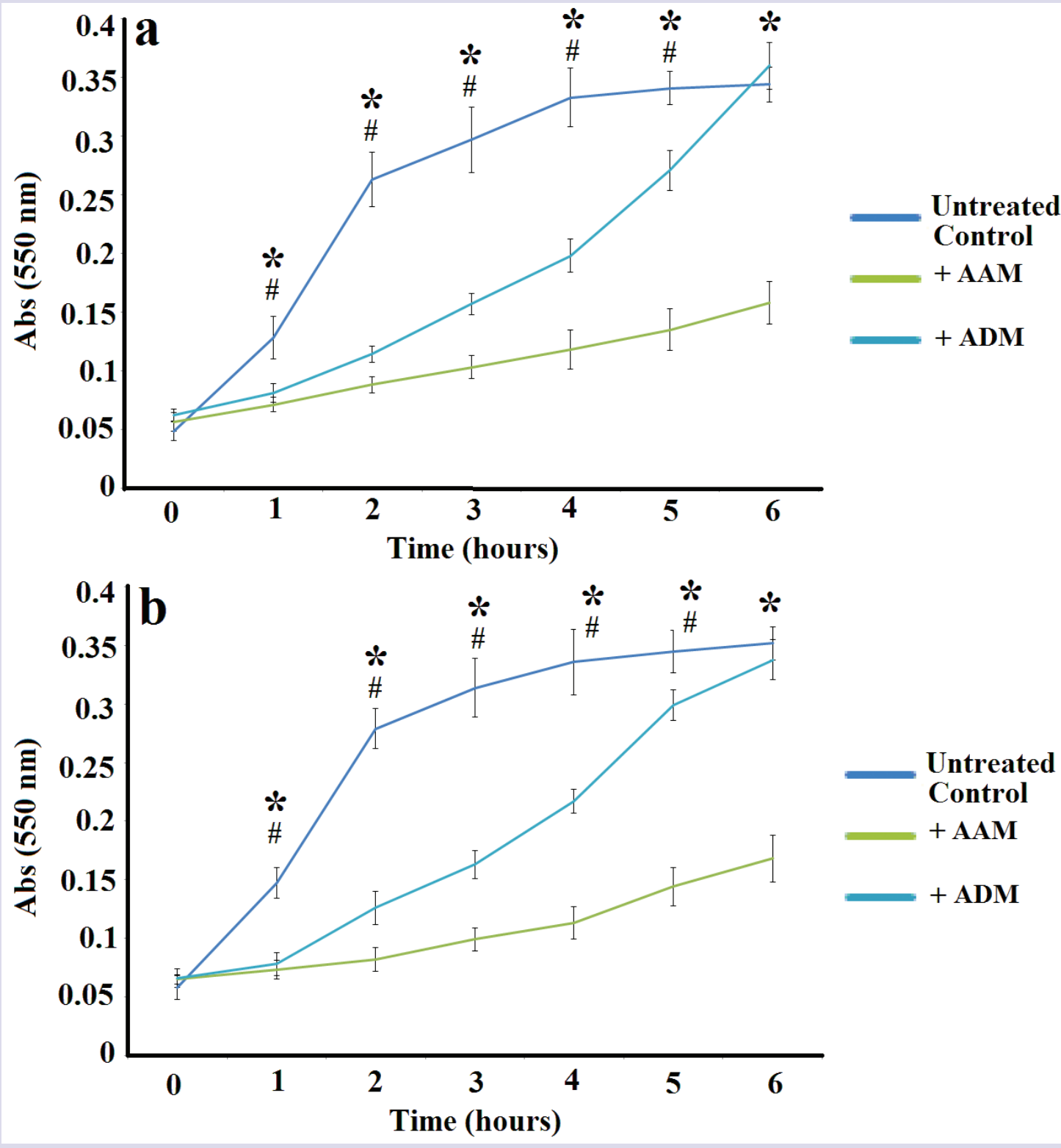

Figure 4: Bacterial growth curves for the methanolic A. auriculformis and A. disparrima leaf extracts against (a) K. pneumoniae and (b) P. mirabilis. All bioassays were performed in at least triplicate and are expressed as mean $\pm \mathrm{SEM}$. $\mathrm{AAM}=$ A. auriculformis methanolic extract; $\mathrm{ADM}=A$. disparrima methanolic extract; ${ }^{*}=$ results that are significantly different between the treated and the untreated control growth $(p<0.01)$.

potential for chemical induced health problems. Edible plants could potentially provide a source of inhibitory substances for food-borne pathogens and bacteria associated with food spoilage. This study reports on the antimicrobial activities of A. auriculformis, A. disparrima and A. leptoloba leaf extracts, and on their toxicity. The gram positive and gram negative bacteria tested in this study demonstrated similar susceptibilities towards the Acacia spp. extracts. Previous studies with other plant species generally report a greater susceptibility of gram positive bacteria towards solvent extracts for South American, ${ }^{34}$ African ${ }^{35}$ and Australian plant extracts ${ }^{36,37}$ although examples of plants having a greater effect on gram negative bacteria have also been reported. ${ }^{24,38}$

The bacteria examined in this study were chosen because they are all important in food spoilage and/or food poisoning/intoxication. Staphylococcus spp. (especially $S$. aureus) is one of the most common sources of food borne diseases worldwide. ${ }^{1}$ B. cereus and B. subtilise, ${ }^{39}$ E. coli, ${ }^{40}$ C. freundii ${ }^{41}$ and $K$. pneumoniae $e^{41}$ all produce toxins and other proteins that induce gastroenteritis and diarrheal diseases. Many of these toxins are heat stable and are not destroyed by heat treatments/pasteurisation. Therefore, control of these bacteria in food is particularly important. Similarly, $P$. mirabilis releases factors that stimulate histamine production resulting in gastrointestinal, neurological (palpitations, headaches, itching), cutaneous (hives, rash) and hypertension symptoms. ${ }^{42}$ Whilst storage of food at refrigerated temperatures inhibits the growth of many of these pathogenic bacteria, the inclusion of antibacterial food components would further enhance food safety.

Of the pathogenic/toxic bacteria tested in this study, Staphylococcus spp. are generally considered to be the most common source of food poisoning worldwide. ${ }^{1}$ S. aureus and S. epidermidis were each inhibited by $10(67 \%)$ 


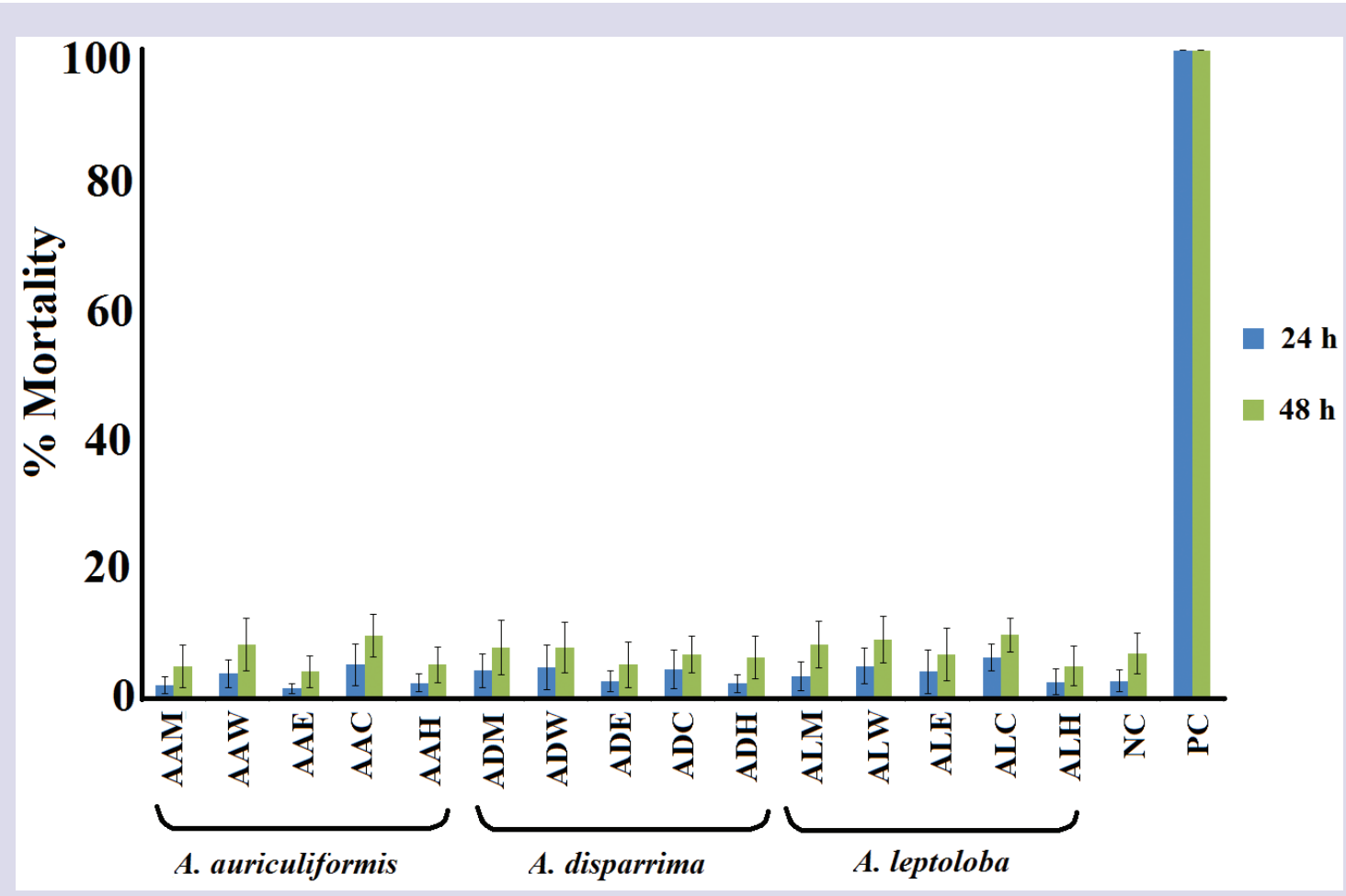

Figure 5: The lethality of the $A$. auriculformis, $A$. disparrima and $A$. leptoloba leaf extracts $(2000 \mu \mathrm{g} / \mathrm{mL})$, potassium dichromate $(1000 \mu \mathrm{g} / \mathrm{mL})$ and a seawater control. $\mathrm{AAM}=\mathrm{A}$. auriculformis methanolic extract; $\mathrm{AAW}=\mathrm{A}$. auriculformis aqueous extract; $\mathrm{AAE}=A$. auriculformis ethyl acetate extract; $\mathrm{AAC}=\mathrm{A}$. auriculformis chloroform extract; $\mathrm{AAH}=A$. auriculformis hexane extract; $\mathrm{ADM}=A$. disparrima methanolic extract; $\mathrm{ADW}=A$. disparrima aqueous extract; $\mathrm{ADE}=A$. disparrima ethyl acetate extract; $\mathrm{ADC}=A$. disparrima chloroform extract; $\mathrm{ADH}=$. disparrima hexane extract; $\mathrm{ALM}=A$. leptoloba methanolic extract; $\mathrm{ALW}=\mathrm{A}$. leptoloba aqueous extract; $\mathrm{ALE}=A$. leptoloba ethyl acetate extract; $\mathrm{ALC}=A$. leptoloba chloroform extract; $\mathrm{ALH}=A$. leptoloba hexane extract; $\mathrm{NC}=$ negative $($ seawater) control; $\mathrm{PC}=$ positive control $(1000 \mu \mathrm{g} / \mathrm{mL}$ potassium dichromate). All bioassays were performed in at least triplicate and are expressed as mean \pm SEM.

of the 15 plant extracts tested. Most of the extracts capable of inhibiting $S$. aureus growth displayed potent activity, with MIC values generally $<1000 \mu \mathrm{g} / \mathrm{mL}$ and as low as $109 \mu \mathrm{g} / \mathrm{mL}$ (A. auriculformis methanolic extract). With the exception of $S$. sonnei, all pathogenic bacteria were inhibited by at least 1 of the extracts. Of the bacteria associated with food poisoning, A. faecalis, K. pneumoniae and P. mirabilis were particularly susceptible. The potent anti-Proteus activity has further therapeutic implications as Proteus mirabilis has been shown to be a trigger of rheumatoid arthritis (RA) and several plant species have already been highlighted as inhibitors of RA via Proteus mirabilis inhibition. ${ }^{43}$

Also particularly interesting was the ability of the extracts to inhibit the growth of psychrotrophic bacteria. Many foods are stored below $5^{\circ} \mathrm{C}$ in refrigerators to retard bacterial growth. These foods are expected to have long shelf lives, in some cases up to 50 days or more. Between processing and consumption, foods may become temperature abused to $10^{\circ} \mathrm{C}$ or higher, allowing psychrotrophic bacteria (e.g. A. faecalis, A. hydrophilia, $B$. cereus and $P$. fluorescens) to cause spoilage. Some pathogenic bacteria are also psychrotrophic (e.g. B. cereus and some strains of C. freundii, E. coli and K. pneumoniae). ${ }^{39-42}$ Therefore, food based antibacterial agents with inhibitory activity against psychrotrophic bacteria are especially useful. All of the psychrotrophic bacteria tested were inhibited by at least 1 Acacia spp. extracts. The A. auriculformis leaf methanolic extract was the strongest and most versatile inhibitor of the psychrotrophic bacteria associated with spoilage, based on the number of MIC's and the number of psychrotrophic bacteria inhibited. Indeed, that extract blocked the growth of every psychrotrophic bacterial species tested. Furthermore, this extract generally displayed low MIC values, indicating that it may be especially useful.
Also noteworthy was the ability of many of the extracts to limit the growth of spore forming bacteria. Heat treatment/pasteurisation is commonly used as a method of destroying food bacteria prior to processing and storage. However, when a bacterium produces heat resistant spores (as B. cereus does) heat treatment may kill the bacteria present, only to have further $B$. cereus growth occurring from the spores. As B. cereus is also psychrotrophic, it is especially difficult to control. All methanolic and aqueous $A$. auriculformis, $A$. disparrima and A. leptoloba leaf extracts demonstrated good inhibitory activity against $B$. cereus (all with MIC values substantially $<1000 \mu \mathrm{g} / \mathrm{mL}$ ). Therefore their incorporation into prepared/processed foods may be a valuable method of controlling $B$. cereus induced food spoilage and food poisoning.

The current study focussed on the effect of $A$. auriculformis, A. disparrima and $A$. leptoloba leaf extracts on aerobic bacteria. However, the anaerobic spore forming bacteria Clostridium botulinium is of greater concern to the food industry due to its incidence and the severity of the symptoms seen with botulism poisoning. ${ }^{44}$ Future studies into the effects of A. auriculformis, A. disparrima and A. leptoloba leaf extracts on anaerobes, including $C$. botulinium are warranted to further evaluate their usefulness as food preservatives.

Individual extract components responsible for the antimicrobial potential of the plant extracts were not identified in the current study. However, qualitative screening studies were used to determine the classes of compounds present. Several commonalities were noted: the most potent aqueous, methanolic and ethyl acetate extracts all contained relatively high levels of tannins and flavonoids. Many studies have reported potent growth inhibitory activities for a number of tannin compounds. 
Gallotannins have been reported to inhibit the growth of a broad spectrum of bacterial species ${ }^{45}$ through a variety of mechanisms including binding cell surface molecules including lipotoichoic acid and proline-rich cell surface proteins, ${ }^{46,47}$ and by inhibiting glucosyltransferase enzymes. ${ }^{48}$ Elligitannins are also highly potent inhibitors of bacterial growth, with MIC values as low as $62.5 \mu \mathrm{g} / \mathrm{mL} .{ }^{45,47}$ Ellagitannins have also been reported to function via several antibiotic mechanisms including interaction with cytoplasmic oxidoreductases and by disrupting bacterial cell walls. ${ }^{45,47}$ Thus, it is likely that Acacia spp. leaf tannins may contribute to the inhibition of bacterial growth reported in our study. It is also likely that other phytochemical classes may contribute to the growth inhibitory properties of these extracts. Further phytochemical evaluation studies and bioactivity driven isolation of active $A$. auriculformis, A. disparrima and $A$. leptoloba leaf extract components is required to further evaluate the mechanism of bacterial growth inhibition.

The findings reported here also demonstrate that none of the A. auriculformis, A. disparrima and A. leptoloba leaf extracts displayed significant toxicity towards Artemia franciscana nauplii. Previously, compounds with an $\mathrm{LC}_{50}>1000 \mu \mathrm{g} / \mathrm{mL}$ towards Artemia nauplii have been defined as being nontoxic. ${ }^{33}$ None of the extracts tested in this study displayed $\mathrm{LC}_{50}$ values $<1000 \mu \mathrm{g} / \mathrm{mL}$. It was therefore determined that all A. auriculformis, A. disparrima and A. leptoloba leaf extracts examined in this study were nontoxic.

\section{CONCLUSIONS}

The results of this study demonstrate the potential of A. auriculformis, A. disparrima and A. leptoloba leaf extracts to block bacterial food spoilage and food poisoning. Furthermore, the broad spectrum antimicrobial activity and the low MICs indicate the potential of the Acacia spp. extracts as natural food preservatives. Further evaluation of the antibacterial properties of these extracts against a more extensive panel of microbial agents is warranted. Likewise, purification and identification of the bioactive components is needed to examine the mechanisms of action of these agents.

\section{ACKNOWLEDGEMENTS}

The authors are grateful to Philip Cameron for providing the plant material used in this study. We are also grateful to Michelle Mendell and Jane Gifkins for the gift of the clinical isolate bacterial strains. Financial support for this work was provided by the Environmental Futures Research Institute and the School of Natural Sciences, Griffith University, Australia.

\section{CONFLICTS OF INTEREST}

The authors report no conflicts of interest.

\section{ABBREVIATIONS}

DMSO: Dimethyl sulfoxide; $\mathbf{L C}_{50}$ : The concentration required to achieve 50\% mortality; MIC: minimum inhibitory concentration.

\section{REFERENCES}

1. Mead PS, Slutsker L, Dietz V, et al. Food related illness and death in the United States. Emerging Infectious Diseases. 1999;5:607-25. http://dx.doi.org/10.3201/ eid0505.990502 http://dx.doi.org/10.3201/eid0506.990625; PMid:10511517

2. Ray B, Bhunia A. Fundamental Food Microbiology. 4th edition 2008; CRC Press, Boca Raton, USA.

3. Cherry JP. Improving the safety of fresh produce with antimicrobials. Food Technology. 1999;53(11):54-9

4. Simon RA. Adverse reactions to food additives. Current Allergy and Asthma Reports. 2004; 3(1): 62-66. http://dx.doi.org/10.1007/s11882-003-0014-9

5. McCann D, Barrett A, Cooper A, Crumpler D, Dalin L, Grimshaw K, et al. Food additives and hyperactive behaviour in 3 -year-old and 8/9-year-old children in the community: a randomised, double-blinded, placebo-controlled trial. Lancet. 2007;370:1560-7. http://dx.doi.org/10.1016/S0140-6736(07)61306-3

6. Gould GW. Industry perspectives on the use of natural antimicrobials and inhibitors for food applications. Journal of Food Protection Supplement. 1996;82-6.

7. Vesoul J, Cock IE. The Potential of Bunya Nut Extracts as Antibacterial Functional Food Agents. Pharmacognosy Communications. 2012;2(1):72-9. DOI: 10.5530/pc.2012.1.13 http://dx.doi.org/10.5530/pc.2012.1.13

8. Boyer $\mathrm{H}$, Cock IE. Evaluation of the potential of Macadamia integriflora extracts as antibacterial food agents. Pharmacognosy Communications. 2013;3(3):53-62 DOI: $10.5530 / p c .2013 .3 .10$

9. Cock IE. Antimicrobial activity of Syzygium australe and Syzygium leuhmannii leaf methanolic extracts. Pharmacognosy Communications. 2012;2(2):71-7. DOI: 10.5530/pc.2012.2.11 http://dx.doi.org/10.5530/pc.2012.2.11

10. Mohanty S, Cock IE. Bioactivity of Syzygium jambos methanolic extracts: Antibacterial activity and toxicity. Pharmacognosy Research. 2010;2(1):4-9. http:// dx.doi.org/10.4103/0974-8490.60577 ; PMid:21808530 PMCid:PMC3140127

11. Cock IE, Mohanty S. Evaluation of the antibacterial activity and toxicity of Terminalia ferdinandia fruit extracts. Pharmacognosy Journal. 2011;3(20):72-9. http:// dx.doi.org/10.5530/pj.2011.20.14

12. Wright $\mathrm{MH}$, Matthews $\mathrm{B}$, Arnold MSJ, et al. The prevention of fish spoilage by high antioxidant Australian culinary plants: Shewanella putrefaciens growth inhibition. International Journal of Food Science and Technology. 2016; DOI: 10.1111/ijfs.13026 http://dx.doi.org/10.1111/ijfs.13026

13. Ali M, Antimicrobial metabolites from Australian Acacia, PhD thesis, 1998, University of Western Australia.

14. Arias ME, Gomez JD, Cudmani NM, Vattuone MA, Isla MI. Antibacterial activity of athanolic and aqueous extracts of Acacia aroma Gill. Ex Hook et Arn, Life Sciences. 2004;75:191-202. http://dx.doi.org/10.1016/j.Ifs.2003.12.007; PMid:15120571

15. Seigler DS. Phytochemistry of Acacia sensu-lato, Biochemical Systematics and Ecology. 2003;845-73. http://dx.doi.org/10.1016/S0305-1978(03)00082-6

16. Hegarty MP, Hegarty EE, Food safety of Australian bushfoods, publication no. 01/28, 2001, Rural Industries Research and Development Corporation, Australia. PMCid:PMC97920

17. Latz PK, Bushfires and bushtucker: Aboriginal plant use in Central Australia, IAD Press 1995; Alice Springs, NT, Australia.

18. Maen A, Cock IE. Inhibitory activity of Australia culinary herb extracts against the bacterial triggers of selected autoimmune diseases. Pharmacognosy Communications. 2015; 5(2): 130-139. DOI: 10.5530/pc.2015.2.4 http://dx.doi. org/10.5530/pc.2015.2.4

19. Kalotas A, Goddard C, Punu, Yankunytjatjara plant use, Institute for Aboriginal Development 1985; Alice Springs, NT, Australia

20. Cock IE, Medicinal and aromatic plants - Australia, in Ethnopharmacology section, Biological, Physiological and Health Sciences, Encyclopedia of Life Support Systems (EOLSS), 2011; Developed under the Auspices of the UNESCO, EOLSS Publishers, Oxford ,UK, (http://www.eolss.net).

21. Lassak EV, McCarthy T, Australian Medicinal Plants 1993; Reed publishers, Australia.

22. Arkhipov A, Sirdaarta J, Rayan P, et al. An examination of the antibacterial, antifungal, anti-Giardial and anticancer properties of Kigelia africana fruit extracts. Pharmacognosy Communications. 2014;4(3):62-76. DOI: 10.5530/pc.2014.3.7 http://dx.doi.org/10.5530/pc.2014.3.7

23. Kalt FR Cock IE Gas chromatography-mass spectroscopy analysis of bioactive Petalostigma extracts: Toxicity, antibacterial and antiviral activities. Pharmacognosy Magazine 2014; 10 (Suppl 1): S37-49. DOI: 10.4103/0973-1296.127338 http://dx.doi.org/10.4103/0973-1296.127338

24. Lee CJ, Wright MH, Arnold MSJ, et al. Inhibition of Streptococcus pyogenes growth by native Australian plants: New approaches towards the management of impetigo, pharyngitis and rheumatic heart disease. Pharmacognosy Communications 2016; 6(3): 164-173. DOI: 10.5530/pc.2016.3.6 http://dx.doi. org/10.5530/pc.2016.3.6

25. Courtney R, Sirdaarta J, Matthews B, et al. Tannin components and inhibitory activity of Kakadu plum leaf extracts against microbial triggers of autoimmune inflammatory diseases. Pharmacognosy Journal. 2015;7(1): 18-31. http://dx.doi. org/10.5530/pj.2015.7.2

26. Cock IE. Antimicrobial activity of Acacia aulacocarpa and Acacia complanta methanolic extracts. Pharmacognosy Communications. 2012:2(1):66-71. DOI: 10.5530/pc.2012.1.12 http://dx.doi.org/10.5530/pc.2012.1.12

27. Wright $\mathrm{MH}$, Lee $\mathrm{CJ}$, Pollock $\mathrm{CE}$, et al. Growth inhibitory activity of selected high antioxidant Australian Syzygium species against the food poisoning and tissue necrotic pathogen Clostridium perfringens. Pharmacognosy Communications. 2016;6(2):93-9. DOI : 10.5530/pc.2016.2.7 http://dx.doi.org/10.5530/ pc.2016.2.7

28. Sautron C, Cock IE. Antimicrobial activity and toxicity of Syzygium australe and Syzygium leuhmanii fruit extracts. Pharmacognosy Communications. 2014;4(1):53-60. DOI: 10.5530/pc.2014.1.8 http://dx.doi.org/10.5530/pc.2014.1.8

29. Hart C, Ilanko P, Sirdaarta J, et al. Tasmannia stipitata as a functional food/natural preservative: Antimicrobial activity and toxicity. Pharmacognosy Communications. 2014; 4(4): 33-47. DOI: 10.5530/pc.2014.4.4 
30. Cock IE. Antimicrobial activity of Acacia aulacocarpa and Acacia complanta methanolic extracts. Pharmacognosy Communications. 2012;2(1):66-71. DOI: 10.5530/pc.2012.1.12 http://dx.doi.org/10.5530/pc.2012.1.12

31. Cock IE. Assessment of the toxicity of selected Australian native plant extracts using the Artemia franciscana nauplii bioassay. Internet Journal of Toxicology 2008; 5: 2 .

32. Ruebhart DR, Wikramasinghe WA, Cock IE. Protective efficacy of the antioxidants vitamin $\mathrm{E}$ and Trolox against Microcystis aeruginosa and microcystin-LR in Artemia franciscana nauplii. Journal of Toxicology and Environmental Health Part A. 2009;72(24): 1567-1575. http://dx.doi.org/10.1080/15287390903232459; PMid:20077231

33. Cock IE, Ruebhart DR. Comparison of the brine shrimp nauplii bioassay and the ToxScreen-II test for the detection of toxicity associated with Aloe vera (Aloe barbadensis Miller) leaf extract. Pharmacognosy Research. 2009;1(2):98-101.

34. Paz EA, Cerdeiras MP, Fernandez J, Ferreira F, Moyna P, Soubes M, et al. Screening of Uruguayan medicinal plants for antimicrobial activity. Journal of Ethnopharmacology. 1995;45:67-70. http://dx.doi.org/10.1016/0378-8741(94)01192-3

35. Kudi AC, Umoh JU, Eduvie LO, Gefu J. Screening of some Nigerian medicinal plants for antibacterial activity. Journal of Ethnopharmacology. 1999;67:225-8. http://dx.doi.org/10.1016/S0378-8741(98)00214-1

36. Cock IE. Antibacterial activity of selected Australian native plant extracts. Internet Journal of Microbiology. 2008; 4: 2.

37. Cock IE. Antimicrobial activity of Eucalyptus major and Eucalyptus baileyana methanolic extracts. Internet Journal of Microbiology. 2008; 6: 1.

38. Cock IE, Kukkonen L. An examination of the medicinal potential of Scaevola spinescens: Toxicity, antibacterial, and antiviral activities. Pharmacognosy Research. 2011;3(2):85-94. DOI: 10.4103/0974-8490.81955 http://dx.doi.org/10.4103/09748490.81955
39. Granum PE. Bacillus cereus, In Food borne Pathogens: Microbiology and Molecular Biology, Fratamico PM, Bhunia AK, Smith JL. Caister Academic Press 2005; Norfolf, UK.

40. Nataro JP, Kaper JB. Diarrheagenic Eschericia coli. Clinical Microbiology Reviews. 1998;11(1):142-201. PMid:9457432 PMCid:PMC121379

41. Twedt RM, Boutin BK. Potential public health significance of non-Eschericia coli coliforms in food. Journal of Food Protection. 1979;42:161-3.

42. Bean NH, Griffin PM, Goulding JS, et al. Food borne disease outbreaks, 5 year summary, 1983-1987. Journal of Food Protection. 1990;53:711-28.

43. Cock IE, van Vuuren SF. Anti-Proteus activity of some South African medicinal plants: Their potential for the prevention of rheumatoid arthritis. Inflammopharmacology. 2013;21: DOI 10.1007/s10787-013-0179-3. http://dx.doi.org/10.1007/ s10787-013-0179-3

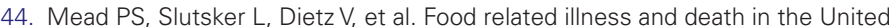
States. Emerging Infectious Diseases. 1999;5:607-25. http://dx.doi.org/10.3201/ eid0505.990502 : http://dx.doi.org/10.3201/eid0506.990625 ; PMid:10511517

45. Buzzini $P$, Arapitsas $P$, Goretti M, et al. Antimicrobial activity of hydrolysable tannins. Mini-Reviews in Medicinal Chemistry. 2008:8:1179-87. http://dx.doi. org/10.2174/138955708786140990; PMid:18855732

46. Wolinsky LE, Sote EO. Isolation of natural plaque-inhibiting substances from 'Nigerian chewing sticks'. Caries Research. 1984;18:216-25. http://dx.doi. org/10.1159/000260768

47. Hogg SD, Embery G. Blood-group-reactive glycoprotein from human saliva interacts with lipoteichoic acid on the surface of Streptococcus sanguis cells. Archives in Oral Biology. 1982;27:261-8. http://dx.doi.org/10.1016/00039969(82)90060-7

\section{PICTORIAL ABSTRACT}

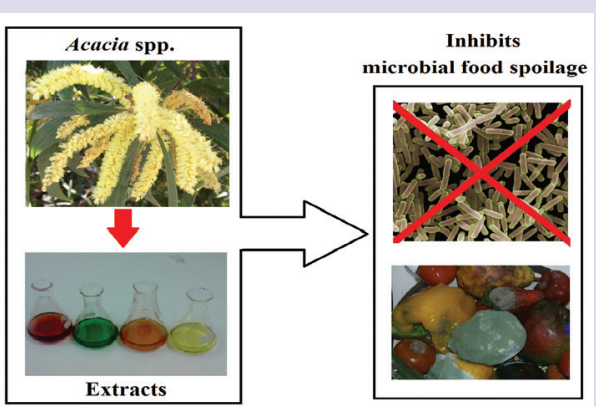

\section{SUMMARY}

- A. auriculiformis and A. disparrima leaf extracts display broad spectrum antibacterial activity against gram positive and gram negative bacteria.

- Methanolic A. auriculiformis extract was a particularly potent inhibitor of K. pneumoniae, P. mirabilis, B. cereus and S. aureus growth (MICs of 97, 132,178 and $109 \mu \mathrm{g} / \mathrm{mL}$ respectively).

- Methanolic $A$. auriculiformis extract was also a good inhibitor of $A$. faecalis, A. hydrophilia and S. newport growth (MIC's $<1000 \mu \mathrm{g} / \mathrm{mL}$ range).

- The A. disparrima extracts were similarly potent inhibitors of bacterial growth.

- All A. auriculiformis, A. disparrima and A. leptoloba leaf extracts were nontoxic.

\section{ABOUT AUTHORS}

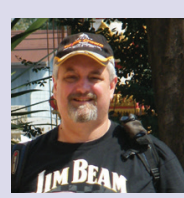

Dr lan Cock leads a research team in the Environmental Futures Research Institute and the School of Natural Sciences at Griffith University, Australia. His research involves bioactivity and phytochemical studies into a variety of plant species of both Australian and international origin, including Aloe vera, South Asian and South American tropical fruits, as well as Australia plants including Scaevola spinescens, Pittosporum phylliraeoides, Terminalia ferdinandiana (Kakadu plum), Australian Acacias, Syzygiums, Petalostigmas and Xanthorrhoea johnsonii (grass trees). This range of projects has resulted in nearly 200 publications in a variety of peer reviewed journals. 